\title{
Do parents drink their children's welfare? Intra-household allocation of time between market labour, domestic work and child care in Russia
}

\author{
Gianna Claudia Giannelli ${ }^{1}$, Lucia Mangiavacchi ${ }^{2}$ and Luca Piccoli ${ }^{2 *}$
}

\author{
*Correspondence: \\ luca.piccoli@uib.es \\ ${ }^{2}$ Department of Applied \\ Economics, University of the \\ Balearic Islands, Ctra de Valldemossa \\ km 7.5, Palma de Mallorca, Spain \\ Full list of author information is \\ available at the end of the article
}

\begin{abstract}
The aim of this paper is to investigate whether parental alcohol consumption leads to a reduction of child welfare. To this end, we analyse whether alcohol consumption decreases parents' time spent looking after children and working. Using the Russia Longitudinal Monitoring Survey, we estimate a model of intra-household allocation of time for mono-nuclear families with children under fifteen years of age. We find that fathers' alcohol consumption has a negative impact on their weekly hours spent doing child care, while no significant effect is observed for mothers' alcohol consumption.
\end{abstract}

JEL codes: $D 1 ; 11 ; J 13 ; J 22$

Keywords: Child care; Time allocation; Alcohol consumption; Labour supply; Russia

\section{Springer}

\section{Introduction}

It is a widely recognized fact that alcohol consumption is a major risk factor for morbidity and mortality. Higher morbidity and mortality rates, however, are not the only negative consequences of alcohol addiction. Alcoholism is also known as a family disease, since it may lead to serious health and socio-economic problems, not only in the short-run, but also in the long-run, through the transmission of its harmful effects to offspring. Parental alcoholism may negatively affect children in several ways. Many children of alcoholics have common symptoms such as low self-esteem, loneliness, guilt, feelings of helplessness, fears of abandonment, and chronic depression (Berger 1993; Chatterji and Markowitz, 2001). Unfortunately, these and other more dramatic consequences, such as domestic violence, psychological alienation, and deprivation of affection, are difficult to be measured through general purpose socio-economic surveys.

When parents regularly consume alcohol, they may reduce time spent in child care. Furthermore, children may also be affected through the negative effects of one parent's alcohol consumption on the other spouse. Family responsibilities may shift from two parents to one parent and, as a result, the non-alcoholic parent may also reduce time spent in looking after children. In all such cases, a negative impact of alcohol consumption on child care time would imply a welfare loss for the child.

(C2013 Giannelli et al.; licensee Springer. This is an Open Access article distributed under the terms of the Creative Commons Attribution License (http://creativecommons.org/licenses/by/2.0), which permits unrestricted use, distribution, and reproduction in any medium, provided the original work is properly cited. 
Information on parents' time devoted to child care and on individual alcohol consumption can be fruitfully exploited to infer about the influence of alcohol consumption on parents' effort towards their children. Therefore, one viable way of studying the effects of parents' alcohol consumption on children is through parents' time-use. This is possible thanks to the increasing availability of more detailed data on the use of time within the household. Using time use data, in this paper we propose a model to test the effects of parental alcohol consumption on child care time.

To our knowledge, this is the first study to address the problem of the effects of alcohol consumption on the allocation of time within the household. So far, the economic literature has focused on the effects of alcoholism on individual labour market outcomes, based mainly on U.S. data, finding an unclear effect of alcohol abuse on labour supply. For instance, Mullahy and Sindelar (1991) and French et al (1998) explore respectively gender differences in labour force participation in response to alcoholism and alcohol abuse on the labour supply of young men. Interestingly, Hamilton and Hamilton (1997) find that moderate alcohol consumption leads to higher earnings relative to abstinence, while heavy drinking leads to reduced wages relative to moderate drinking. More recently, and again based on U.S. data, Feng et al (2001) finds that problem drinking has a negative but non-significant impact on employment for women, and a positive and significant impact for men, suggesting the importance of modelling the impact of alcohol consumption on labour supply decisions separately for males and females. French et al (2011) find that alcohol misuse is significantly related to employment problems, suggesting that the transmission mechanism that links alcohol consumption and labour supply works through a conflictive behaviour between supervisor and colleagues.

Russia is a particularly interesting setting in which to study the socio-economic consequences of drinking. Alcohol consumption was the third leading cause of death during the Soviet regime (Baltagi and Geishecker, 2006), and was one of the main causes of increased mortality during the transition decades (Brainerd and Cutler, 2005). Tekin (2004) has exploited the Russia Longitudinal Monitoring Survey (RLMS-HSE) to estimate the effects of alcohol consumption on employment and wages for males and females during transition. His estimates reject the hypothesis of an inverse U-shaped relationship between alcohol consumption and employment outcomes found in Hamilton and Hamilton (1997). Instead, the impact of alcohol consumption turns out to be nonsignificant as far as labour supply is concerned, yet positive and linear for both male and female wages levels.

Moreover, during the 90s, child care services in Russia declined as a result of economic transition to a market economy, and their cost increased substantially, so that low income families could not afford them anymore. As a result, after transition, Russian couples have to rely massively on child care provided by household members (Lokshin, 2004), and, since child care is so crucial for children's welfare, the question as to whether child care time provided by parents could be affected by alcohol consumption appears particularly relevant.

Our paper uses a sample of households drawn from the RLMS-HSE to investigate whether alcohol consumption reduces the time that parents spend with their children, thus changing the intra-household allocation of time in an unfavourable way for children. In line with recent advances in household economics, we analyse the time allocation decisions of partners under the assumption that this is jointly determined by members of the 
household across various activities. We estimate an SUR Tobit system using Full Information Maximum Likelihood, accounting for a possible correlation of the errors among time-use equations, simultaneously for the husband and the wife. Our model presents some similarities and some differences with respect to Bloemen et al (2010). It is similar in that it treats the time use choices of both spouses jointly and analyses the same time use categories. It is different in that it allows us to explicitly deal with the problem of sample selection bias in labour supply and to endogenise wages in the decision process.

Our results suggest that a father's alcohol consumption significantly reduces the time he devotes to child care, while no effects are observed for mothers' alcohol consumption. Moreover, we do not find any effect of one spouse's alcohol consumption on the other spouse. We interpret these findings as evidence of a negative impact of fathers' alcohol consumption on child welfare.

The paper is structured as follows: a section on Background literature reviews the relevant economic literature on allocation of time within the household and on the effects of alcohol consumption; a section on Theoretical foundations outlines the theoretical framework; a section on the Empirical strategy describes the empirical specification, while data and variables used are presented in the section on Data. Section Results discusses the findings of the empirical analysis, and the last section concludes.

\section{Background literature}

Spouses' allocation of time has been treated jointly since Chiappori $(1988,1992)$ while time dedicated to domestic tasks has been endogenised since Gronau (1977), GrossbardShechtman (1984), Kooreman and Kapteyn (1987) and Apps and Rees (1996), that extended the original time use model proposed by Becker (1965). In the recent empirical literature, it is a common practice to separate child care time from domestic tasks ${ }^{1}$.

Studies on the determinants of parental child care have been based mostly on systems of simultaneous equations for paid work and child care time of individuals, as in Kalenkoski et al $(2005,2007,2009)$, mainly using the American Time Use Survey and the U.K. Time Use Study. Kimmel and Connelly (2007) include both domestic tasks and child care. They use data for the U.S. to estimate a four-equation system in which the dependent variables are the minutes used in household production, leisure activities, paid work, and child care by mothers. Their main finding is a substantial, positive wage elasticity for care time, while both leisure and household production time decline with increased wages.

One strand of literature studies one partner's choices conditioning on spouse's decisions, distinguishing between different activities and modelling them jointly. Powell (2002), for example, examines the impact of child care prices and wage rates on the joint employment and child care decisions of married mothers in Canada. She finds that wages have a positive impact on the probability of choosing any of the working states and that child care prices for centre, sitter, and relative care reduce the probability of working and using each respective mode of care. Connelly and Kimmel (2009) extend the model proposed by Kimmel and Connelly (2007) considering the effect of spouse's characteristics on time devoted to leisure, child care, and home production of married mothers and fathers. Their results show little effect of one spouse on the unpaid time use of the partner, while the relative wage does not affect time use choices. In Russia, Lokshin et al (2000) and Lokshin (2004) focus again on mothers, modelling simultaneously household demand for child care, mothers' labour force participation and mothers' working hours. Both studies 
do not restrict the sample to single unit households, so the inclusion of multi-nuclear families implies the need to control for not only the wage of the husband, but also the average wage of all other family members. Their results show that mothers' labour force participation and working hours are responsive to changes in the price of child care and hourly wages. Additionally, (Lokshin 2004) evidences the ineffectiveness of family allowances transfers on a household's choice of child care arrangements.

In a growing number of studies both female and male partners' choices regarding the different types of activities are modelled jointly. Child care time allocation is substantially different between spouses ${ }^{2}$, and, since female and male child care times are not orthogonal, they should be modelled jointly. Hallberg and Klevmarken (2003), for example, develop a simultaneous equation framework for child care and paid work. Using panel data for Sweden, they find that a change in the mother's working hours has less influence on the parents' time with their children than a change in the father's working hours. Using a similar methodology, Garcia-Mainar et al (2011) estimate a joint model of parental child care time for five European countries. Bloemen et al (2010) analyse simultaneously the time allocated by husband and wife to paid work, child care and housework in Italy. They find that spouses time allocation is sensitive to personal and household characteristics, such as education and children's age. Men married to more highly educated women spend more time with their children and the husband's own characteristics have little effect on wives' time allocation.

As far as the case of Russia is concerned, during the 90s, child care institutions in Russia, as well as female labour force participation, declined as a result of the economic transition from a socialist to a market economy. At the same time, the cost of child care supplied by the government increased, making daycare services unaffordable for low income families with young children. Lokshin et al (2000) and (Lokshin 2004) use the 1994 - 1996 rounds of RLMS to estimate a model of consumer demand for state provided child care and find that mothers' decisions to send children to formal child care and to participate in the labour market are taken jointly. They find that the cost of private child care is a disincentive to participation, while public transfers in the form of family allowances are ineffective. Similarly, Grogan and Koka (2010) estimate a discrete choice model of mothers' labour force participation for a longer panel and find an even stronger negative effect for having children under 3 in the 2000s. As a result, during the 90s, in-home care increased to levels ranging from $69.4 \%$ to $99.9 \%$ of total child care time, depending on child age. These findings suggest that Russian couples, after the economic transition, have to rely almost completely on informal child care provided within the household.

As for alcohol consumption, it is well known that in Russia alcohol consumption is high, with effects on health that increase morbidity and mortality. Brainerd and Cutler (2005) suggest that the increase in alcohol consumption is one of the leading causes of the dramatic positive trend in mortality rates during transitional years, accounting for about $25 \%$ of the increased mortality ${ }^{3}$. Moreover, consumption of vodka is more likely to be binge rather than moderate drinking (Brainerd and Cutler, 2005; Baltagi and Geishecker, 2006). During the transition to a market economy, positive trends in alcohol consumption patterns were observed by several studies, all of them using RLMS data. Zohoori et al (1998) and Brainerd and Cutler (2005) found that in the early 1990s, per-capita consumption of alcohol doubled in particular among middle-aged men. In the following years, this upward trend was interrupted by an increase in the price of alcohol, until 1998 when it 
started to rise again (RLMS data suggest an increase of $27 \%$ in alcohol consumption in the whole period 1992-2000). The last five waves of RLMS (2006-2010) partially confirm the previous trends, with total daily alcohol intake for drinkers showing a slight increase for males and an essentially stable path for females.

\section{Theoretical foundations}

A bulk of literature, starting with Grossbard-Shechtman (1984) for marriage market models and Apps and Rees (1996) within the collective framework, have formulated utility models that account for both the multi-person nature of many households and the inclusion of household production. In these models, time allocation decisions of male and female partners are jointly determined, as well as the allocation of time among the different types of activities.

The model proposed here is grounded in this stream of literature and presents three main features: i) child care time is included as a separate time use category as in Kimmel and Connelly (2007) and Connelly and Kimmel (2009), ii) husbands' and wives' time use are jointly determined as in Bloemen et al (2010), and iii) information on individual alcohol consumption is exploited to test its impact on individual allocation of time and on intra-household distribution of domestic tasks and paid work.

In theory, as was postulated by Becker (1981), parents are assumed to have altruistic preferences towards the other family members. This assumption implies the inclusion of partner's and child's welfare among the arguments of each parent's utility function. In particular, parents have the following altruistic utility functions:

$$
\begin{aligned}
U_{m} & =U_{m}\left(t_{m}^{l}, z_{m}^{a}, U_{f}, U_{c}\right) \\
U_{f} & =U_{f}\left(t_{f}^{l}, z_{f}^{a}, U_{m}, U_{c}\right) \\
U_{c} & =U_{c}\left(z^{c}\right)
\end{aligned}
$$

where $m$ and $f$ represent male and female partners, $t^{l}$ is leisure time, $z^{a}$ is a composite consumption good consumed by each adult (such that $z_{m}^{a}+z_{f}^{a}=z^{a}$ ), produced as a combination of household production time of the two partners and of intermediate goods and services purchased in the market $z^{a}=g\left(t_{m}^{d}, t_{f}^{d}, \mathbf{x}\right) . z^{c}$ is a composite good consumed by the children and produced as a combination of child care time of the two partners and goods and services purchased in the market $z^{c}=g\left(t_{m}^{c}, t_{f}^{c}, \mathbf{x}\right)$. It follows that each parent's utility can, without loss of generality, be rewritten as:

$$
U_{i}=U_{i}\left(t_{m}^{l}, t_{f}^{l}, z_{m}^{a}, z_{f}^{a}, z^{c}\right)
$$

Assuming that the adults take responsibility for maximizing family welfare, they maximize household utility subject to the constraints of both their own time as well as that of the household budget:

$$
\begin{aligned}
T_{m} & =t_{m}^{w}+t_{m}^{d}+t_{m}^{c}+t_{m}^{l} \\
T_{f} & =t_{f}^{w}+t_{f}^{d}+t_{f}^{c}+t_{f}^{l} \\
\mathbf{p}^{\prime} \mathbf{x} & =w_{f} t_{f}^{w}+w_{m} t_{m}^{w}+v
\end{aligned}
$$

where $w, d, c$ and $l$ are time use categories (paid work, domestic tasks, child care and leisure time respectively), $v$ is household non-labour income, and $\mathbf{p}^{\prime} \mathbf{x}$ is household expenditure on market goods. It is worth noting that such a specification is general and 
embraces both unitary and collective decision models depending on how household utility is specified. The solution of the model yields the supply functions of the uses of time for both partners:

$$
t_{i}^{k}=t_{i}^{k}\left(w_{i}, w_{j}, v\right)
$$

where, for each individual $(i=m, f)$ each time use category $(k=c, d, w, l)$ depends on wages $\left(w_{i}\right.$ and $\left.w_{j}\right)$, household non-labour income $(v)$ and the structure of preferences ${ }^{4}$. Family and personal characteristics, indeed, can be included in the time use functions as preference factors.

The system defined by the paid work, domestic tasks and child care equations for each partner (leisure equations are excluded to avoid collinearity), as previously stated, is potentially compatible with a collective specification (see, for example, Bourguignon, 1999; Mangiavacchi et al, 2010; Dunbar et al, 2013). However, as the data includes no child exclusive goods (for parents we could use the respective leisure times), it would be impossible to identify the child sharing rule. Thus, the use of a collective model would imply an unnecessary burden, at least for the aims of this paper.

As detailed in the next section, our empirical strategy is to estimate the reduced form equation system (4). Even though this strategy does not allow us to fully recover the structural parameters of preferences, it still allows us to determine the impact of an exogenous variable on the time use equations. In our context, child care time directly affects child consumption, and, by consequence, what affects child care time, also affects child welfare. The child's utility depends on the amount of good $z^{c}$ that the child consumes, which, in turn, have child care time among its production input factors. By assumption, in fact, the time devoted to child care has a strictly positive productivity: a larger amount of time input increases $z^{c}$. In turn, $z^{c}$ has a strictly positive marginal utility for the child. This implies that an exogenous variable that significantly reduces child care time, also significantly reduces $z^{c}$. However, since $z^{c}$ also depends on purchased goods $\mathbf{x}$, a parent might renounce to some child care time in favour of paid work time, thus increasing child utility by increasing expenditure on $\mathbf{x}$. However, if an exogenous variable negatively affects child care time and has no positive impacts on market labour time of both partner, then there would be an unquestionable negative impact on child welfare. We apply this line of reasoning to understand the transmission mechanism of the effects of alcohol consumption on child welfare.

\section{Empirical strategy}

The empirical specification of the system of equations (4) involves considering several factors to avoid biased estimates. Each time use equation is left censored, since, for some individuals, the minimum amount of child care, domestic tasks or paid work is zero. A suitable econometric model in this case would be a type-1 Tobit (Amemiya, 1985). This specification, however, may be problematic. In fact, non-workers' potential wages must be estimated, and the empirical literature widely recognizes the possibility of a sample selection bias. One solution is to estimate wages independently for men and women in a first stage using a Heckman selection model (Heckman, 1979). Moreover, estimating the wage equations using a Heckman selection model implies estimating a labour participation equation. So, labour supply equations in (4) could also be estimated more precisely if estimated jointly with this labour participation equation. This is possible using a system 
in which one participation equation is used by two different equations, namely the wage and labour supply equations. Finally, our theoretical model requires the reduced form equations to be estimated jointly, allowing for possible correlation among the error terms. In fact, since our unit of observation is the family, we have to take into account that the amount of time devoted to one activity by one individual not only depends on time spent in other activities, but also on time spent in this and other activities by his/her partner. For example, the mother's child care time will depend on her paid work status (being on leave, working part time or full time, and so on), but also on her husband's paid work: if he works more hours, she might carry out more child care, and vice-versa.

In sum, our empirical specification is a SUR consisting of four equations for the partners' child care and domestic tasks (specified as type- 1 Tobit, since almost all individuals participate in these activities, so that the number of censored observations is reasonably small), and six equations for the partners' labour participation, labour supply and wages (specified as a type-5 Tobit). Each partner has five equations two of which are for child care and for domestic tasks and are specified as:

$$
\begin{aligned}
t_{i}^{k *} & =\beta_{0}+\beta_{a_{i}} a_{i}+\beta_{a_{j}} a_{j}+\beta_{w_{i}} w_{i}+\beta_{w_{j}} w_{j}+\beta_{\nu} v+\beta_{P_{i}}^{\prime} \mathbf{P}_{\mathbf{i}}+\beta_{F_{i}}^{\prime} \mathbf{F}+u_{i, k} \\
t_{i}^{k} & =t_{i}^{k *} \text { if } t_{i}^{k *}>0 \\
t_{i}^{k} & =0, \text { otherwise, }
\end{aligned}
$$

with $i, j=f, m$ indicating the partner, either female $(f)$ or male $(m), k=d, c$ representing domestic tasks $(d)$ or child care $(c), a_{i, j}$ being individual alcohol consumption, and $\mathbf{P}_{\mathbf{i}}$ and $\mathbf{F}$ personal and family characteristics ${ }^{5}$. The other three equations are for labour market participation, labour supply and wage, and are specified as:

$$
\begin{aligned}
d_{i}^{*} & =\beta_{X_{i}}^{\prime} \mathbf{X}_{\mathbf{i}}+e_{i} \\
w_{i}^{*} & =\beta_{Z_{i}}^{\prime} \mathbf{Z}_{\mathbf{i}}+v_{i} \\
t_{i}^{w *} & =\beta_{0}+\beta_{a_{i}} a_{i}+\beta_{a_{j}} a_{j}+\beta_{w_{i}} w_{i}+\beta_{w_{j}} w_{j}+\beta_{v} v+\beta_{P_{i}}^{\prime} \mathbf{P}_{\mathbf{i}}+\beta_{F_{i}}^{\prime} \mathbf{F}+u_{i, w} \\
d_{i} & =1 \text { if } d_{i}^{*}>0 \\
d_{i} & =0 \text { otherwise } \\
t_{i}^{w} & =t_{i}^{w *} \text { if } d_{i}^{*}>0 \\
t_{i}^{w} & =0, \text { otherwise } \\
w_{i} & =w_{i}^{*} \text { if } d_{i}^{*}>0 \\
w_{i} & =0, \text { otherwise, }
\end{aligned}
$$

with the dummy $d_{i}^{*}$ indicating the participation equation, $w_{i}^{*}$ the wage equation and $t_{i}^{w *}$ the labour supply equation for member $i$.

The exogenous variables, presented in the next section, include economic variables, such as partners' potential wages and non-labour income, and other individual and household characteristics, including our relevant variable of interest, namely, alcohol consumption by each partner.

It is worth stressing that, in our model, parents' attitude towards alcohol might be endogenous. One weakness of our analysis is that we were not able to find a suitable instrument to apply an instrumental variable estimation technique ${ }^{6}$.

The whole system is composed by 10 equations: 6 for the use of time (paid work, $t_{i}^{w}$, domestic tasks, $t_{i}^{d}$ and child care, $t_{i}^{c}$, for $i=m, f$ ), 2 labour market participation equations 
and 2 wage equations. The resulting error structure is slightly more complex than a standard SUR. The error terms are drawn from a multivariate normal distribution with zero mean and a $10 \times 10$ covariance matrix, correlation between the error terms is allowed between time-use equations and own-wage equations, but participation equations are allowed to be correlated only with their own labour supply and wage equation. So, for the avoidance of doubt, correlation is not allowed between female labour market participation and male wage, or between male labour market participation and male child care time. Correlation is allowed for all other equations, so, for instance, the error term in the female wage equation may be correlated with the error term in the female domestic tasks equation.

The covariance matrix, thus, takes the following form

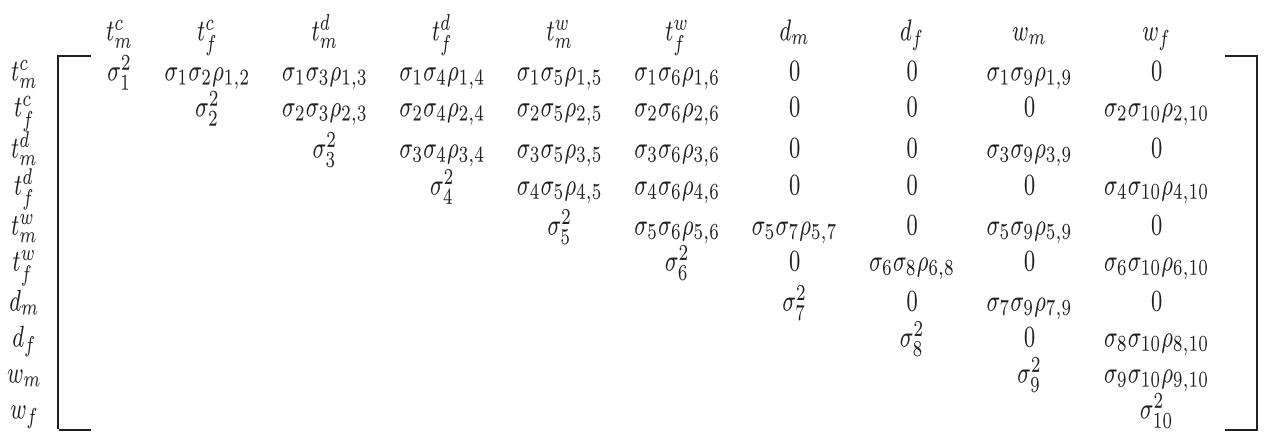

where $\sigma_{i}^{2}$ indicates the variance of error term $i, \sigma_{i} \sigma_{i} \rho_{i, j}$ indicates the covariance between two error terms $i$ and $j$, and $\rho_{i, j}$ indicates the correlation coefficients, with $i, j=1, \ldots, 10 \equiv u_{m, c}, u_{f, c}, u_{m, d}, u_{f, d}, u_{m, w}, u_{f, w}, e_{m}, e_{f}, v_{m}, v_{f}$.

The system is estimated by Full Information Maximum Likelihood using the aML statistical software ${ }^{7}$.

\section{Data}

The empirical analysis is based on four rounds (XV to XVIII, spanning from 2006 to 2009) of the Russia Longitudinal Monitoring Survey (RLMS-HSE), conducted by the Higher School of Economics and ZAO Demoscop together with the Carolina Population Center, University of North Carolina at Chapel Hill and the Institute of Sociology RAS ${ }^{8}$. The survey has two phases: during the first phase of the project (1992 -1994), the RLMS collected four rounds of data; in the second phase, until 2011, the RLMS collected sixteen further rounds of data. Households participating in the survey were selected trough a multi-stage probability sampling procedure in order to guarantee national representativeness. Within each selected primary sample unit, the population was stratified into urban and rural substrata in order to guarantee representativeness of the sample in both areas. Between rounds XV and XVIII, the data covers approximately 5,000 households, 12,000 adults and 2,000 children per wave.

Since the RLMS was originally designed to monitor the health impact of economic transition in Russia, it contains detailed information on alcohol consumption of the respondents, use of time and labour supply. The RLMS permits the identification of the relationship between each member in the household, not only with respect to the head of the household. This allows us to select only households with no more than one nuclear 
family, avoiding problems due to the presence of more than one family with children in the same household ${ }^{9}$. This could amount to a serious issue, since, as was found by Lokshin et al (2000) and Lokshin (2004), the share of extended families in Russia increased substantially during the transition period, and more than half of Russian children live in extended families. The availability of the relationship between all household members also permits the identification of the number of potential suppliers of non-parental informal child care in the family, such as grandparents. Therefore, even if multifamily households are excluded from the analysis, we have kept in the sample households with co-resident grandparents.

Individual alcohol consumption is recorded by the RLMS for all rounds of Phase II. However, only from round XV it is possible to identify the actual monthly consumption. The dataset is also rich in time-use information, even if time spent in domestic activities and informal care is recorded only from rounds XV to XVIII ${ }^{10}$. In these four rounds, time use is recorded within the labour module of the survey, where people declared minutes spent per day in different activities in the last 30 days both during working days and weekends.

It is worth noting that, due to the sampling design, it was not possible to construct a household panel data-set, because families are not uniquely identified over time. While it is rather easy to track individuals, a unique family identifier cannot be constructed. For example, consider two subsequent waves in which a household splits because a son gets married. It is not possible to follow this family over time because: i) the two new families maintain the old household identification number that refers to the previous wave, but for the current wave one keeps the same identification number and the other gets a new one, ii) cross sectional identification numbers may be different in the way they are constructed (in round XV the family identifier received one more digit, and a change in the sample design in round XVIII implied that identification numbers are constructed using different stratification variables). The combination of these two conditions together with the explicit recommendation of HSE to not reconstruct a certain wave identification number using a different wave stratification data, prevented us from building a household panel data-set ${ }^{11}$.

So, despite the advantages of a panel data-set, we were forced to pool the four waves into a cross section. In particular, we took all families present in round XVIII and added families from the previous waves that were not present in that round ${ }^{12}$.

The dependent variables included in the system of equations are the logarithms of weekly hours spent respectively in child care ${ }^{13}$, domestic tasks ${ }^{14}$ and paid work. Even though time-use patterns may differ between weekdays and weekends, weekly amounts are used since alcohol consumption is not recorded separately for weekends and weekdays. Regarding time-use categories, as previously mentioned, to identify the effect of parental alcohol consumption on child welfare we separate child care from domestic tasks, as in Kimmel and Connelly (2007), Connelly and Kimmel (2009) and Bloemen et al (2010). Average weekly child care hours are 9.7 hours for men and 15.3 hours for women. Domestic tasks time is 12.9 hours for men and 22.8 hours for women, and paid work time on average is 42.1 hours for men and 31.4 hours for women (see Table 1).

Table 2 shows the joint distribution of time use categories and alcohol consumption for the sample under analysis ${ }^{15}$. It can be seen that fathers rarely carry out more child 
Table 1 Overall scores across all the thirty-nine participants under each condition

\begin{tabular}{|c|c|c|c|c|}
\hline \multirow[b]{2}{*}{ Individual variables } & \multicolumn{2}{|c|}{ Husband } & \multicolumn{2}{|c|}{ Wife } \\
\hline & Mean & SD & Mean & SD \\
\hline Weekly childcare hours & 9.6805 & 10.6318 & 15.3346 & 13.1642 \\
\hline Weekly domestic work hours & 12.9085 & 12.4256 & 22.8007 & 12.8250 \\
\hline Weekly market work hours & 42.0895 & 20.3362 & 31.3644 & 20.1227 \\
\hline Grams of alcohol per day / BMI & 0.5379 & 0.9884 & 0.1314 & 0.4132 \\
\hline Ln of wage rate & 4.2715 & 0.7401 & 3.9438 & 0.6884 \\
\hline Age & 35.3745 & 7.4685 & 32.8741 & 7.1889 \\
\hline Non-Russian & 0.2727 & - & 0.2448 & - \\
\hline Pension (not retired) & 0.0505 & - & 0.0249 & - \\
\hline Primary education & 0.2821 & - & 0.4367 & - \\
\hline Tertiary education & 0.3963 & - & 0.2580 & - \\
\hline Occasional drinker & 0.7172 & - & 0.5975 & - \\
\hline Frequent drinker & 0.0583 & - & 0.0054 & - \\
\hline Pregnant & - & - & 0.0163 & - \\
\hline Self-reported health status (cat.) & 2.5144 & 0.5964 & 2.6169 & 0.5995 \\
\hline Disability + Chronic illness & 0.3326 & 0.5063 & 0.3691 & 0.5063 \\
\hline Number of cigarettes & 11.3108 & 10.2433 & 2.2688 & 5.0365 \\
\hline Household variables & \multicolumn{2}{|c|}{ Mean } & \multicolumn{2}{|c|}{ SD } \\
\hline Number of children [0-1] & \multicolumn{2}{|c|}{0.0785} & \multicolumn{2}{|c|}{0.2719} \\
\hline Number of children [4-6] & \multicolumn{2}{|c|}{0.6263} & \multicolumn{2}{|c|}{0.6206} \\
\hline Number of children [0-3] & \multicolumn{2}{|c|}{0.3737} & \multicolumn{2}{|c|}{0.5329} \\
\hline Presence of a nursery in the community & \multicolumn{2}{|c|}{0.5975} & \multicolumn{2}{|c|}{0.4906} \\
\hline Community males/females ratio & \multicolumn{2}{|c|}{0.9987} & \multicolumn{2}{|c|}{0.0572} \\
\hline Community male/female wage ratio & \multicolumn{2}{|c|}{1.2138} & \multicolumn{2}{|c|}{0.1224} \\
\hline Community average wage & \multicolumn{2}{|c|}{50.0878} & \multicolumn{2}{|c|}{13.3053} \\
\hline Receive help with childcare (cat.) & \multicolumn{2}{|c|}{0.4476} & \multicolumn{2}{|c|}{0.5904} \\
\hline Ln of non labour income & \multicolumn{2}{|c|}{6.0025} & \multicolumn{2}{|c|}{3.5253} \\
\hline Dwelling dimension (cat.) & \multicolumn{2}{|c|}{1.9751} & & \\
\hline Number of grandparents & & & & \\
\hline Number of uncles & & & & \\
\hline Dwelling dimension (cat.) & & & & \\
\hline Owner of dwelling & & & & \\
\hline Female headed household & & & & \\
\hline Region 1 - Metropolitan area & & & & \\
\hline Region 2 - Northern area & & & & \\
\hline Region 3 - Central area & & & & \\
\hline Region 4 - Volga & & & & \\
\hline Region 5 - Caucas & & & & \\
\hline Region 6 - Ural & & & & \\
\hline Region 7 - West Siberia & & & & \\
\hline Region 8 - East Siberia & & & & \\
\hline Round XV & & & & \\
\hline Round XVI & & & & \\
\hline Round XVII & & & & \\
\hline Round XVIII & & & & \\
\hline
\end{tabular}

1287 observations.

care than mothers, but still almost $60 \%$ of them dedicate at least 5 hours weekly to child care. This figure rises to $75.4 \%$ for mothers. The domestic tasks rely even more heavily on women. Almost $42 \%$ of husbands do less than 10 weekly hours of domestic tasks, 
Table 2 Joint distribution of child care, domestic tasks, paid work and alcohol consumption

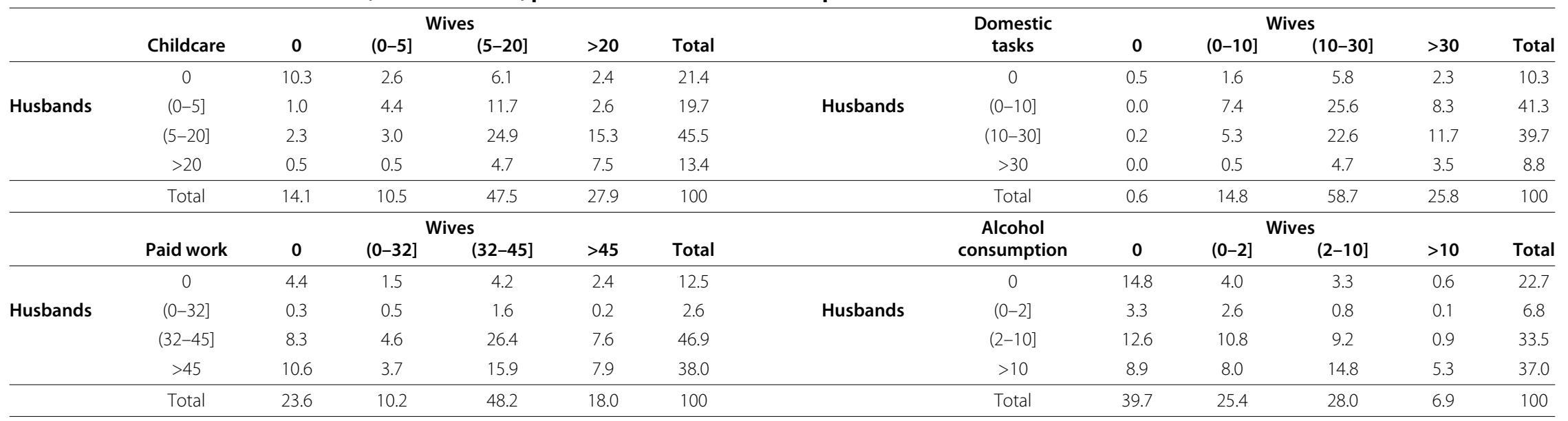

1287 observations. In hours per week (childcare, domestic tasks and paid work) and grams of pure alcohol per day. 
while almost $85 \%$ of wives do more than 10 hours. The situation changes respect to paid work, where only $15 \%$ of fathers are unemployed or part-time workers, with an impressive $38 \%$ of overtime workers. Women, however, do show large percentages of full-time and overtime work: $48 \%$ and $18 \%$ respectively.

As to the drinker's profile, drinking is mostly a male phenomenon (see Baltagi and Geishecker, 2006). Table 1 shows that in our sample more than $77 \%$ of men reported drinking, either occasionally (71.7\%) or frequently - drinking every day or almost every day - (5.8\%). For women, these figures are $59.8 \%$ and $0.5 \%$, respectively. A substantial difference is also present in the level of consumption. As shown by Figure 1, male drinkers drink at least twice as much as women. Baltagi and Geishecker (2006) also show that male drinkers are likely to be married, to have children, to be well educated and to have a higher household income than non-drinkers.

In the RLMS, individual alcohol consumption is self-reported by the respondent in the health module. In Russia, alcohol consumption is measured in grams instead of litres, so each respondent is asked to declare how many grams of beer, wine, fortified wine, home-made liquor, vodka, and other alcoholic beverages they usually drink per day during the last 30 days. However, only from round $\mathrm{XV}$ it is possible to identify the actual monthly consumption, since respondents have also to declare the days per month they have been drinking. Following Baltagi and Geishecker (2006), these amounts are adjusted for pure alcohol content in order to make the various types of alcoholic beverages comparable and then summed up to compute total individual alcohol consumption. The weights used are $5 \%$ for the alcohol content of beer, $10 \%$ for wine, $19 \%$ for fortified wine, $45 \%$ for home made liquor, $40 \%$ for vodka, and $20 \%$ for other alcohol. Finally, the alcohol variables included in the equations are computed as the logarithm of grams of total alcohol intake per week, and divided by the body mass index of the person, in order to control for the possibly different impact of similar amounts of alcohol on different sized individuals. As to the possible doubts on the validity of self-reported measures of alcohol consumption, we follow the idea, again found in Baltagi and Geishecker (2006), that self-declared alcohol consumption in Russia should not be under-reported, since there is no social stigma

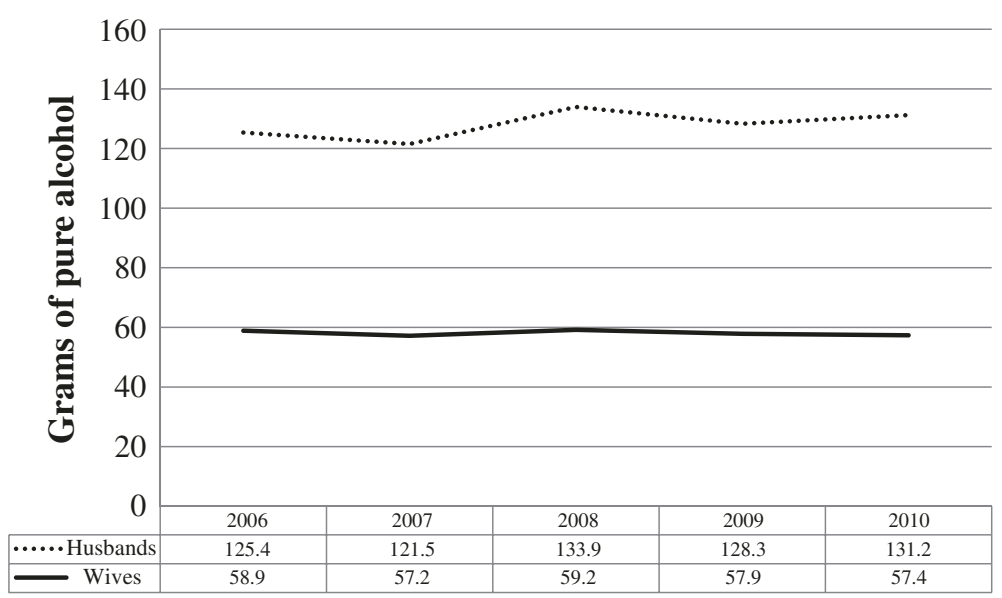

Figure 1 Evolution of alcohol consumption, 2006-2010. Note: Average daily grams of pure alcohol consumed by drinkers. 
attached to alcohol consumption within the country. Recall errors are still possible, but at least there should not be a clear negative bias in the declared quantities.

The figures presented in Table 2 confirm that alcohol in Russia is mainly a male phenomenon. More than $70 \%$ of fathers drink more than 2 grams of pure alcohol per day (on average) and 37\% more than 10 grams (that corresponds to 25 grams - a small glass of vodka). $10 \%$ of males drink more than 30 grams of alcohol per day (not shown in the table). Women drink much less, most of them (65\%) consuming less than 2 grams of alcohol per day, which amounts approximately to one glass of vodka per week. Only a few consume more than one glass of vodka per day (less than 7\%) and almost $40 \%$ are abstemious (compared with $23 \%$ of males).

Although the focus of this paper is on the effects of alcohol on child welfare, wages are a critical variable that needs special attention in the analysis. As already discussed, previous analyses on the relation between alcohol and wages suggest a positive correlation (see Tekin, 2004). Thus a wage equation for each of the spouses is included in the system, and to correct possible self-selection bias, correlation between the error terms of the wage equation and the equation for labour participation is allowed.

Other explanatory variables included in the model (see Table 1 ) are the number of children in the age ranges of $0-1,0-3$ and 4-6, the number of grandparents and uncles living in the household, a dummy for being an entrepreneur, the health status (a categorical indicator equal to one in presence of chronic illness or disability and 2 if both of them are present, and a dummy indicating if receiving some pension, excluding retirement pension), whether the household receives help with child care by relatives not living in the household, the number of cigarettes per day and a standard list of individual demographic controls (age, education, nationality). We also control for the economic condition of the household, using non-labour income, dwelling ownership, and dwelling size. Finally, some regional variables are included, namely, average males/females ratio, male/female wage ratio, average wage, regional dummies and a dummy indicating the presence of a nursery in the community.

The sample selection starts by keeping mothers and fathers in the age 17-65 with children younger than 15 for the four waves and excluding multi-nuclear families (approximately 4400 households). Repeated households are then dropped by the sample (about 3100). Eliminating inconsistent observations, for example those with zero salary and a positive amount of worked hours, leads to the final sample, which is composed of 1287 households.

Given the complexity of the empirical specification, it is worth specifying the exclusions restrictions that help identifying the model ${ }^{16}$. First, the participation equation includes variables that are excluded both from the labour supply and the wage equations. In addition, the wage equation should include some variables not present in the labour supply equation. Thus, we have three sets of exclusion restrictions. The first set concerns the participation equation with the labour supply equation where the excluded variables are: being an occasional drinker, being pregnant (wives only), the number of children in the age range $0-1$, dwelling ownership, and three dummies identifying the waves of the panel. The second set of restrictions concerns the participation with the wage equation, where the excluded variables are: average males/females ratio, receive help with child care, number of grandparents, being pregnant, number of children aged $0-3$, being non-Russian and being in bad health conditions. Finally, the 
third set of restrictions concerns the wage equation with the labour supply equation, and the excluded variables are: being an occasional drinker, having only primary education, number of children aged $0-1$, dwelling ownership, and the three waves dummies.

\section{Results}

Tables 3 and 4 present the estimated parameters of the empirical model introduced in Section "Theoretical foundations". As to the joint nature of the decision processes, the significance of cross equation correlations and of most of the reciprocal variables suggest that the choice of the joint estimation approach is appropriate.

As to the main focus of this paper, our results suggest that the amount of consumed alcohol is a relevant factor in determining fathers' child care time, influencing negatively and significantly (at 5\%) their weekly hours spent in this activity. Manually computing the average partial effect ${ }^{17}$ of one additional gram of pure alcohol per day for the average male drinker -who drinks 9.7 grams of pure alcohol per day and has a BMI of 25.9- implies a reduction of 2.5 minutes of child care time per week. In our opinion this is a rather large effect. Indeed, drinking one more grass of vodka per day, which contains about 10 grams of pure alcohol, reduces fathers' child care time by almost half an hour. Along this line, drinking 5 glasses more would imply a reduction of more than two hours with respect to an average of 9.7 hours.

According to our theoretical specification, this effect can be interpreted as a negative effect of the father's alcohol consumption on child welfare. Alcohol reduces the time fathers devote to children, thus reducing the amount of child composite good $z^{c}$ produced and, therefore, children's utility. Mothers' alcohol consumption, instead, has no significant effect on child care. Also, for both parents, it has no significant effect on household income, either through hours of work or in regards to wages, so that we do not observe a compensation for the welfare loss through an increase in market goods expenditure, $\mathbf{x}$. This result is in line with Tekin (2004), who finds that alcohol consumption has no significant effect on employment and wages for either males or females.

We find, however, a positive effect of moderate drinking on paid work that is probably linked to the social aggregation value that occasional drinking may generate, especially in a country like Russia, where drinking is not associated with social stigma. This is observed through a positive and significant effect of being an occasional drinker on labour participation for husbands and wives. Moreover, being an occasional drinker has a positive effect on wives' wages. Again, this is in line with previous findings of a positive association between moderate drinking and earnings (Berger and Leigh,1988; Zarkin et al, 1998; MacDonald and Shields, 2001).

In the absence of other studies on the effects of alcohol consumption on the couples' use of time, a comparison can be done with a recent study on the effects of alcohol consumption on the intra-household distribution of resources in Italy (Menon et al, 2012). The authors find that husbands' alcohol consumption significantly reduces wives' shares of economic resources (while the reverse is not true), thus significantly affecting wives' well-being.

The presence of a nursery in the community positively influences participation to the labour market for both parents, and significantly increases the hours of paid work by the wife. This is expected, but it produces a further positive result that at first might seem 


\section{Table 3 SUR Tobit estimation}

\begin{tabular}{|c|c|c|c|c|c|c|c|c|c|c|}
\hline & \multicolumn{2}{|c|}{ Childcare } & \multicolumn{2}{|c|}{ Domestic tasks } & \multicolumn{2}{|c|}{ Paid work } & \multicolumn{2}{|c|}{ Labour participation } & \multicolumn{2}{|c|}{ Wage } \\
\hline & Husband & Wife & Husband & Wife & Husband & Wife & Husband & Wife & Husband & Wife \\
\hline Constant & $\begin{array}{l}-2.4704 \\
(2.2833)\end{array}$ & $\begin{array}{l}-1.3490 \\
(2.1725)\end{array}$ & $\begin{array}{c}2.6235 \\
(1.9897)\end{array}$ & $\begin{array}{c}0.8920 \\
(1.0965)\end{array}$ & $\begin{array}{c}3.3917^{* * *} \\
(.63356)\end{array}$ & $\begin{array}{c}4.1657^{* * *} \\
(.83443)\end{array}$ & $\begin{array}{c}0.4759 \\
(1.9652)\end{array}$ & $\begin{array}{c}-4.8002^{* * *} \\
(1.6746)\end{array}$ & $\begin{array}{c}3.0383^{* * *} \\
(.74643)\end{array}$ & $\begin{array}{c}1.8864 \\
(1.2547)\end{array}$ \\
\hline Alcohol & $\begin{array}{c}-0.0973^{* *} \\
(.04751)\end{array}$ & $\begin{array}{l}-0.0079 \\
(.15193)\end{array}$ & $\begin{array}{c}0.0011 \\
(.04072)\end{array}$ & $\begin{array}{l}0.0717 \\
(.08889)\end{array}$ & $\begin{array}{c}0.0168 \\
(.01363)\end{array}$ & $\begin{array}{c}0.0005 \\
(.03917)\end{array}$ & & & $\begin{array}{c}0.0378 \\
(.03354)\end{array}$ & $\begin{array}{c}0.0315 \\
(.25665)\end{array}$ \\
\hline Alcohol-partner & $\begin{array}{l}-0.0612 \\
(.17791)\end{array}$ & $\begin{array}{l}-0.0649 \\
(.04909)\end{array}$ & $\begin{array}{c}0.1009 \\
(.16485)\end{array}$ & $\begin{array}{l}-0.0182 \\
(.02012)\end{array}$ & $\begin{array}{l}-0.0102 \\
(.02972)\end{array}$ & $\begin{array}{c}0.0055 \\
(.01292)\end{array}$ & & & & \\
\hline Occasional drinker & & & & & & & $\begin{array}{c}0.2875^{* * *} \\
(.10298)\end{array}$ & $\begin{array}{c}0.2602^{* * *} \\
(.09161)\end{array}$ & $\begin{array}{c}0.0213 \\
(.05861)\end{array}$ & $\begin{array}{c}0.2328^{* * *} \\
(.08779)\end{array}$ \\
\hline Presence of nursery & $\begin{array}{l}0.2220^{* *} \\
(.09292)\end{array}$ & $\begin{array}{c}0.1101 \\
(.09385)\end{array}$ & $\begin{array}{c}0.1015 \\
(.08241)\end{array}$ & $\begin{array}{l}-0.0060 \\
(.04067)\end{array}$ & $\begin{array}{c}0.0059 \\
(.02411)\end{array}$ & $\begin{array}{l}0.0530^{*} \\
(.03018)\end{array}$ & $\begin{array}{c}0.2354^{* *} \\
(0.1067)\end{array}$ & $\begin{array}{c}0.3068^{* * *} \\
(.09302)\end{array}$ & $\begin{array}{c}0.2318^{* * *} \\
(.05938)\end{array}$ & $\begin{array}{c}0.1172 \\
(.10549)\end{array}$ \\
\hline Males/female ratio & $\begin{array}{l}-0.5220 \\
(1.7697)\end{array}$ & $\begin{array}{c}0.1580 \\
(1.6817)\end{array}$ & $\begin{array}{l}-1.8410 \\
(1.6965)\end{array}$ & $\begin{array}{l}-0.2930 \\
(.71607)\end{array}$ & $\begin{array}{c}1.2559^{* *} \\
(.54703)\end{array}$ & $\begin{array}{c}0.0845 \\
(.59898)\end{array}$ & $\begin{array}{c}0.6353 \\
(1.4627)\end{array}$ & $\begin{array}{c}0.4532 \\
(1.487)\end{array}$ & & \\
\hline Male/female wage ratio & $\begin{array}{c}2.5636^{* * *} \\
(.85723)\end{array}$ & $\begin{array}{l}1.6303^{*} \\
(.84098)\end{array}$ & $\begin{array}{l}-0.0695 \\
(0.7761)\end{array}$ & $\begin{array}{c}0.6723 \\
(0.4211)\end{array}$ & $\begin{array}{c}0.0417 \\
(.19615)\end{array}$ & $\begin{array}{l}-0.1316 \\
(.26162)\end{array}$ & & & & \\
\hline Average wage & $\begin{array}{c}0.0226 \\
(.02217)\end{array}$ & $\begin{array}{c}0.0104 \\
(.02155)\end{array}$ & $\begin{array}{c}0.0061 \\
(.02025)\end{array}$ & $\begin{array}{l}0.0154^{*} \\
(.00848)\end{array}$ & $\begin{array}{c}-0.0139^{* *} \\
(.00606)\end{array}$ & $\begin{array}{l}-0.0056 \\
(.00652)\end{array}$ & & & $\begin{array}{l}-0.0025 \\
(.01056)\end{array}$ & $\begin{array}{l}-0.0145 \\
(.01715)\end{array}$ \\
\hline Help with childcare & $\begin{array}{c}0.1065 \\
(.08128)\end{array}$ & $\begin{array}{l}0.1359^{*} \\
(.08081)\end{array}$ & $\begin{array}{l}-0.0176 \\
(.06574)\end{array}$ & $\begin{array}{l}-0.0340 \\
(0.0267)\end{array}$ & $\begin{array}{l}-0.0045 \\
(.01713)\end{array}$ & $\begin{array}{c}0.0138 \\
(.02067)\end{array}$ & $\begin{array}{c}0.1179 \\
(.08511)\end{array}$ & $\begin{array}{l}0.0996 \\
(.08261)\end{array}$ & & \\
\hline Number of grandparents & $\begin{array}{l}0.3474^{*} \\
(.20054)\end{array}$ & $\begin{array}{c}0.1051 \\
(.21086)\end{array}$ & $\begin{array}{l}-0.2256^{*} \\
(.12052)\end{array}$ & $\begin{array}{c}-0.2156^{* * *} \\
(.06058)\end{array}$ & $\begin{array}{l}-0.0689 \\
(.05016)\end{array}$ & $\begin{array}{c}0.0387 \\
(.05845)\end{array}$ & $\begin{array}{l}-0.2152 \\
(.19973)\end{array}$ & $\begin{array}{l}-0.1534 \\
(.19119)\end{array}$ & & \\
\hline Age & $\begin{array}{l}-0.2966 \\
(.45831)\end{array}$ & $\begin{array}{c}0.0860 \\
(0.3836)\end{array}$ & $\begin{array}{c}0.0073 \\
(.40631)\end{array}$ & $\begin{array}{c}0.0908 \\
(.19774)\end{array}$ & $\begin{array}{c}0.0090 \\
(.10083)\end{array}$ & $\begin{array}{l}-0.1501 \\
(.18565)\end{array}$ & $\begin{array}{c}0.2021 \\
(0.5941)\end{array}$ & $\begin{array}{c}2.6074^{* * *} \\
(.46815)\end{array}$ & $\begin{array}{c}0.4643 \\
(.31869)\end{array}$ & $\begin{array}{l}1.2394^{* *} \\
(.61251)\end{array}$ \\
\hline Age squared & $\begin{array}{c}0.0200 \\
(.05946)\end{array}$ & $\begin{array}{l}-0.0399 \\
(0.0524)\end{array}$ & $\begin{array}{c}0.0106 \\
(.05426)\end{array}$ & $\begin{array}{l}-0.0118 \\
(.02855)\end{array}$ & $\begin{array}{l}-0.0001 \\
(.01351)\end{array}$ & $\begin{array}{c}0.0167 \\
(.02597)\end{array}$ & $\begin{array}{l}-0.0424 \\
(.07642)\end{array}$ & $\begin{array}{c}-0.3543^{* * *} \\
(.06497)\end{array}$ & $\begin{array}{l}-0.0636 \\
(.04227)\end{array}$ & $\begin{array}{l}-0.1529 \\
(.09475)\end{array}$ \\
\hline Age ratio & $\begin{array}{c}0.1530 \\
(.28802)\end{array}$ & $\begin{array}{c}0.0601 \\
(0.2829)\end{array}$ & $\begin{array}{c}0.0248 \\
(.24641)\end{array}$ & $\begin{array}{l}0.2205^{*} \\
(.11664)\end{array}$ & $\begin{array}{l}-0.0054 \\
(.07074)\end{array}$ & $\begin{array}{c}0.1011 \\
(.08344)\end{array}$ & & & & \\
\hline Wage rate & $\begin{array}{c}0.1653^{* * *} \\
(.02927)\end{array}$ & $\begin{array}{c}0.0629^{* *} \\
(.02763)\end{array}$ & $\begin{array}{c}0.0820^{* * *} \\
(.02797)\end{array}$ & $\begin{array}{l}-0.0077 \\
(.01196)\end{array}$ & $\begin{array}{l}-0.0401 \\
(.05082)\end{array}$ & $\begin{array}{l}-0.0021 \\
(.00839)\end{array}$ & & & & \\
\hline Wage rate - partner & $\begin{array}{c}0.0531^{* *} \\
(.02521) \\
\end{array}$ & $\begin{array}{c}0.1408^{* * *} \\
(.02792) \\
\end{array}$ & $\begin{array}{c}0.1277^{* * *} \\
(.02029) \\
\end{array}$ & $\begin{array}{c}0.1560^{* * *} \\
(.01198) \\
\end{array}$ & $\begin{array}{c}-0.0164^{* * *} \\
(.00615) \\
\end{array}$ & $\begin{array}{c}0.0274 \\
(.05179) \\
\end{array}$ & & & & \\
\hline
\end{tabular}


Table 3 SUR Tobit estimation (Continued)

\begin{tabular}{|c|c|c|c|c|c|c|c|c|c|c|}
\hline Non-labour income & $\begin{array}{l}-0.0091 \\
(.01243)\end{array}$ & $\begin{array}{c}0.0072 \\
(.01183)\end{array}$ & $\begin{array}{l}0.0186^{*} \\
(.01071)\end{array}$ & $\begin{array}{c}0.0027 \\
(.00528)\end{array}$ & $\begin{array}{l}-0.0046 \\
(.00285)\end{array}$ & $\begin{array}{l}-0.0043 \\
(.00359)\end{array}$ & & & & \\
\hline Primary education & & & & & & & & & $\begin{array}{c}-0.1410^{* *} \\
(.06987)\end{array}$ & $\begin{array}{l}-0.1645 \\
(.11351)\end{array}$ \\
\hline Tertiary education & $\begin{array}{c}0.0777 \\
(.10471)\end{array}$ & $\begin{array}{l}0.1695^{*} \\
(0.0935)\end{array}$ & $\begin{array}{l}0.1546^{*} \\
(.09346)\end{array}$ & $\begin{array}{c}0.0124 \\
(.04059)\end{array}$ & $\begin{array}{l}-0.0114 \\
(.02297)\end{array}$ & $\begin{array}{l}-0.0319 \\
(.02807)\end{array}$ & & & $\begin{array}{c}0.0078 \\
(.08135)\end{array}$ & $\begin{array}{c}0.0104 \\
(.10996)\end{array}$ \\
\hline Tertiary education - partner & $\begin{array}{c}0.0908 \\
(.09498)\end{array}$ & $\begin{array}{l}-0.0371 \\
(.09415)\end{array}$ & $\begin{array}{l}-0.0512 \\
(.07986)\end{array}$ & $\begin{array}{c}0.0469 \\
(.04188)\end{array}$ & $\begin{array}{c}0.0202 \\
(.02077)\end{array}$ & $\begin{array}{c}0.0350 \\
(.02915)\end{array}$ & & & & \\
\hline Pregnant & & & & & & & & $\begin{array}{l}0.9923^{* *} \\
(.43138)\end{array}$ & & \\
\hline Number of children [0-1] & & & & & & & $\begin{array}{c}0.1190 \\
(.23312)\end{array}$ & $\begin{array}{l}0.3339^{*} \\
(.17092)\end{array}$ & $\begin{array}{l}-0.1292 \\
(.09264)\end{array}$ & $\begin{array}{c}-0.3364^{* *} \\
(.13405)\end{array}$ \\
\hline Number of children [0-3] & $\begin{array}{c}0.7903^{* * *} \\
(.11242)\end{array}$ & $\begin{array}{c}0.4580^{* * *} \\
(.08873)\end{array}$ & $\begin{array}{l}0.2182^{* *} \\
(.09068)\end{array}$ & $\begin{array}{c}-0.1899^{* * *} \\
(0.0412)\end{array}$ & $\begin{array}{l}-0.0048 \\
(.02293)\end{array}$ & $\begin{array}{l}-0.0241 \\
(.03386)\end{array}$ & $\begin{array}{l}-0.1412 \\
(.14257)\end{array}$ & $\begin{array}{c}-0.5732^{* * *} \\
(.12271)\end{array}$ & & \\
\hline Number of children [4-6] & $\begin{array}{c}0.5140^{* * *} \\
(.10317)\end{array}$ & $\begin{array}{c}0.4016^{* * *} \\
(.09974)\end{array}$ & $\begin{array}{c}0.0611 \\
(.08489)\end{array}$ & $\begin{array}{l}0.0754^{*} \\
(.04281)\end{array}$ & $\begin{array}{c}0.0191 \\
(.02234)\end{array}$ & $\begin{array}{c}0.0266 \\
(.03155)\end{array}$ & $\begin{array}{c}0.1072 \\
(.11866)\end{array}$ & $\begin{array}{l}0.1366 \\
(.09601)\end{array}$ & $\begin{array}{c}0.0053 \\
(.05592)\end{array}$ & $\begin{array}{c}-0.2427^{* * *} \\
(.08659)\end{array}$ \\
\hline Non-Russian & $\begin{array}{c}-0.1540^{*} \\
(.09169)\end{array}$ & $\begin{array}{c}-0.3392^{* * *} \\
(.08075)\end{array}$ & $\begin{array}{l}-0.0776 \\
(.08378)\end{array}$ & $\begin{array}{c}0.0309 \\
(.03984)\end{array}$ & $\begin{array}{c}0.0184 \\
(.02526)\end{array}$ & $\begin{array}{c}0.0167 \\
(0.0299)\end{array}$ & $\begin{array}{l}-0.1382 \\
(.15053)\end{array}$ & $\begin{array}{c}-0.3769^{* * *} \\
(.12322)\end{array}$ & & \\
\hline Bad health & $\begin{array}{c}0.1299 \\
(.35899)\end{array}$ & $\begin{array}{l}-0.3613 \\
(.42834)\end{array}$ & $\begin{array}{l}-0.1640 \\
(.29125)\end{array}$ & $\begin{array}{l}-0.0622 \\
(.26532)\end{array}$ & $\begin{array}{l}-0.0561 \\
(.13324)\end{array}$ & $\begin{array}{l}-0.1589 \\
(.39767)\end{array}$ & $\begin{array}{c}-0.1622^{* *} \\
(.07518)\end{array}$ & $\begin{array}{l}0.1131 \\
(.07532)\end{array}$ & & \\
\hline N. of cigarettes & $\begin{array}{c}0.0004 \\
(.00367)\end{array}$ & $\begin{array}{c}0.0097 \\
(.00701)\end{array}$ & $\begin{array}{c}-0.0067^{*} \\
(.00348)\end{array}$ & $\begin{array}{c}0.0010 \\
(.00362)\end{array}$ & $\begin{array}{l}0.0020^{*} \\
(.00104)\end{array}$ & $\begin{array}{c}0.0028 \\
(.00244)\end{array}$ & $\begin{array}{c}0.0017 \\
(.00517)\end{array}$ & $\begin{array}{c}-0.0277^{* * *} \\
(.00823)\end{array}$ & $\begin{array}{c}-0.0097^{* * *} \\
(.00254)\end{array}$ & $\begin{array}{c}0.0148 \\
(0.0104)\end{array}$ \\
\hline Pension (not retired) & $\begin{array}{c}0.2441 \\
(.23874)\end{array}$ & $\begin{array}{c}0.4322 \\
(.33354)\end{array}$ & $\begin{array}{l}-0.2520 \\
(.18329)\end{array}$ & $\begin{array}{c}0.1800 \\
(.24143)\end{array}$ & $\begin{array}{l}-0.0108 \\
(.06597)\end{array}$ & $\begin{array}{l}-0.0473 \\
(.17239)\end{array}$ & & & & \\
\hline Dimension of dwelling & $\begin{array}{c}-0.2221^{* * *} \\
(.05602)\end{array}$ & $\begin{array}{l}-0.0717 \\
(.05409)\end{array}$ & $\begin{array}{c}0.0528 \\
(.05795)\end{array}$ & $\begin{array}{c}0.0022 \\
(.02301)\end{array}$ & $\begin{array}{l}-0.0037 \\
(0.0143)\end{array}$ & $\begin{array}{l}-0.0118 \\
(.01867)\end{array}$ & & & & \\
\hline Owner of dwelling & & & & & & & $\begin{array}{l}-0.1531 \\
(.11509)\end{array}$ & $\begin{array}{c}0.0549 \\
(.09406)\end{array}$ & $\begin{array}{c}0.0408 \\
(.05923)\end{array}$ & $\begin{array}{l}-0.0004 \\
(.08528)\end{array}$ \\
\hline Region 1 (Metropolitan area) & $\begin{array}{l}-0.2783 \\
(.79398)\end{array}$ & $\begin{array}{c}0.0206 \\
(.77319)\end{array}$ & $\begin{array}{l}-0.1243 \\
(.72494)\end{array}$ & $\begin{array}{l}-0.4387 \\
(.30198)\end{array}$ & $\begin{array}{l}0.5077^{* *} \\
(.22991)\end{array}$ & $\begin{array}{c}0.0761 \\
(.24192)\end{array}$ & $\begin{array}{c}0.7092^{* * *} \\
(.24644)\end{array}$ & $\begin{array}{l}-0.0894 \\
(.14753)\end{array}$ & $\begin{array}{l}0.7735^{* *} \\
(.35939)\end{array}$ & $\begin{array}{c}0.7359 \\
(.59509)\end{array}$ \\
\hline Region 2 (Northern area) & $\begin{array}{l}-0.7659 \\
(.67548)\end{array}$ & $\begin{array}{l}-0.0966 \\
(.66009)\end{array}$ & $\begin{array}{l}-0.0949 \\
(.61927) \\
\end{array}$ & $\begin{array}{l}-0.3970 \\
(.26159)\end{array}$ & $\begin{array}{c}0.4676^{* *} \\
(0.1886)\end{array}$ & $\begin{array}{c}0.1597 \\
(.20537) \\
\end{array}$ & $\begin{array}{c}0.2667 \\
(.19294) \\
\end{array}$ & $\begin{array}{l}0.4829^{* *} \\
(.19836)\end{array}$ & $\begin{array}{l}0.5052^{*} \\
(.30064)\end{array}$ & $\begin{array}{c}0.6558 \\
(.48866) \\
\end{array}$ \\
\hline
\end{tabular}




\section{Table 3 SUR Tobit estimation (Continued)}

\begin{tabular}{|c|c|c|c|c|c|c|c|c|c|c|}
\hline Region 3 (Central area) & $\begin{array}{c}0.8178^{* * *} \\
(.25745)\end{array}$ & $\begin{array}{c}0.3788 \\
(.24344)\end{array}$ & $\begin{array}{c}0.1882 \\
(.24919)\end{array}$ & $\begin{array}{l}0.2344^{* *} \\
(.10998)\end{array}$ & $\begin{array}{l}-0.0859 \\
(0.0602)\end{array}$ & $\begin{array}{l}-0.0764 \\
(.07563)\end{array}$ & $\begin{array}{c}0.1561 \\
(0.2337)\end{array}$ & $\begin{array}{c}0.0710 \\
(.22816)\end{array}$ & $\begin{array}{c}0.0470 \\
(.08147)\end{array}$ & $\begin{array}{l}-0.0664 \\
(.11721)\end{array}$ \\
\hline Region 4 (Volga) & $\begin{array}{l}0.5802^{*} \\
(.30451)\end{array}$ & $\begin{array}{c}0.4764 \\
(0.2932)\end{array}$ & $\begin{array}{c}0.0215 \\
(.27678)\end{array}$ & $\begin{array}{c}0.3732^{* * *} \\
(.12313)\end{array}$ & $\begin{array}{l}-0.1434^{*} \\
(.07561)\end{array}$ & $\begin{array}{l}-0.0675 \\
(.08869)\end{array}$ & $\begin{array}{l}0.2689^{*} \\
(.14719)\end{array}$ & $\begin{array}{c}0.1229 \\
(.12529)\end{array}$ & $\begin{array}{l}-0.1828 \\
(.12893)\end{array}$ & $\begin{array}{l}-0.2506 \\
(0.1958)\end{array}$ \\
\hline Round 2 & & & & & & & $\begin{array}{c}0.1999 \\
(.24159)\end{array}$ & $\begin{array}{c}0.2315 \\
(.20336)\end{array}$ & $\begin{array}{c}0.1192 \\
(.12315)\end{array}$ & $\begin{array}{c}0.0312 \\
(.25126)\end{array}$ \\
\hline Round 3 & & & & & & & $\begin{array}{l}-0.0783 \\
(.26127)\end{array}$ & $\begin{array}{c}0.1053 \\
(.20395)\end{array}$ & $\begin{array}{c}0.5002^{* * *} \\
(0.1282)\end{array}$ & $\begin{array}{c}0.2038 \\
(.24058)\end{array}$ \\
\hline Round 4 & & & & & & & $\begin{array}{l}-0.1593 \\
(.21641)\end{array}$ & $\begin{array}{l}0.0481 \\
(.16216)\end{array}$ & $\begin{array}{c}0.4897^{* * *} \\
(.10348)\end{array}$ & $\begin{array}{c}0.1240 \\
(.20468)\end{array}$ \\
\hline
\end{tabular}

1287 observations. *Significance at the $10 \%$ significance level; ** Significance at $5 \% ;{ }^{* * *}$ Significance at 1 Standard error in parenthesis. 
Table 4 Errors variance/covariance matrix for the SUR Tobit estimation

\begin{tabular}{|c|c|c|c|c|c|c|c|c|c|c|}
\hline \multirow{2}{*}{ Variance/covariance matrix } & \multicolumn{2}{|c|}{ Childcare } & \multicolumn{2}{|c|}{ Domestic tasks } & \multicolumn{2}{|c|}{ Paid work } & \multicolumn{2}{|c|}{ Labour participation } & \multicolumn{2}{|c|}{ Wage } \\
\hline & Husband & Wife & Husband & Wife & Husband & Wife & Husband & Wife & Husband & Wife \\
\hline \multirow[t]{2}{*}{ Child care - husband } & $1.2624^{* * *}$ & $0.4741^{* * *}$ & $0.2334^{* * *}$ & $0.1192^{* * *}$ & -0.0389 & -0.0277 & 0.0000 & 0.0000 & $0.0727^{* *}$ & 0.0000 \\
\hline & $(.04129)$ & $(.02274)$ & $(.02865)$ & $(0.0294)$ & $(0.0416)$ & $(0.0359)$ & $(-)$ & $(-)$ & $(.03403)$ & $(-)$ \\
\hline \multirow[t]{2}{*}{ Child care - wife } & & $1.1733^{* * *}$ & $0.1038^{* * *}$ & $0.2084^{* * *}$ & 0.0416 & $-0.0895^{* *}$ & 0.0000 & 0.0000 & 0.0000 & -0.0280 \\
\hline & & $(.03532)$ & $(.03131)$ & $(.03001)$ & $(.04315)$ & $(.04442)$ & $(-)$ & $(-)$ & $(-)$ & $(.04654)$ \\
\hline \multirow[t]{2}{*}{ Domestic tasks - husband } & & & $1.0834^{* * *}$ & $0.1307^{* * *}$ & -0.0202 & 0.0623 & 0.0000 & 0.0000 & $0.1533^{* * *}$ & 0.0000 \\
\hline & & & $(.02657)$ & $(.03288)$ & $(.04223)$ & $(.04157)$ & $(-)$ & $(-)$ & $(.03572)$ & $(-)$ \\
\hline \multirow[t]{2}{*}{ Domestic tasks - wife } & & & & $0.4984^{* * *}$ & 0.0544 & $-0.1085^{*}$ & 0.0000 & 0.0000 & 0.0000 & $-0.1771^{* * *}$ \\
\hline & & & & $(.00902)$ & $(.04014)$ & $(.05668)$ & $(-)$ & $(-)$ & $(-)$ & $(.04442)$ \\
\hline \multirow[t]{2}{*}{ Paid work - husband } & & & & & $0.2524^{* * *}$ & 0.0264 & $-0.3262^{* * *}$ & 0.0000 & -0.1210 & 0.0000 \\
\hline & & & & & $(.00585)$ & $(.04478)$ & $(0.1031)$ & $(-)$ & $(0.1468)$ & $(-)$ \\
\hline \multirow[t]{2}{*}{ Paid work - wife } & & & & & & $0.2939^{* * *}$ & 0.0000 & $0.8627^{* * *}$ & 0.0000 & -0.2366 \\
\hline & & & & & & $(0.0132)$ & $(-)$ & $(0.2845)$ & $(-)$ & $(.17484)$ \\
\hline \multirow[t]{2}{*}{ Labour participation - husband } & & & & & & & 1.0000 & 0.0000 & 0.0921 & 0.0000 \\
\hline & & & & & & & $(-)$ & $(-)$ & $(.08512)$ & $(-)$ \\
\hline \multirow[t]{2}{*}{ Labour participation - wife } & & & & & & & & 1.0000 & 0.0000 & $-0.8781^{* * *}$ \\
\hline & & & & & & & & $(-)$ & $(-)$ & $(.08751)$ \\
\hline \multirow[t]{2}{*}{ Wage - husband } & & & & & & & & & $0.7466^{* * *}$ & $0.1819^{* * *}$ \\
\hline & & & & & & & & & $(.01251)$ & $(.03883)$ \\
\hline \multirow[t]{2}{*}{ Wage - wife } & & & & & & & & & & $1.0645^{* * *}$ \\
\hline & & & & & & & & & & $(.02265)$ \\
\hline
\end{tabular}


counter-intuitive: an increase in husbands' hours of child care. The most likely mechanism that explains this result is that indeed the nursery offers a useful service that allows mothers to work more, but given the rigidities in the labour market contracts - such as the scarce implementation of flexible time contracts - and the inability of nurseries to fully cover the weekly hours of work, husbands may need to compensate with more hours of child care.

As to the other individual variables included in the model, at variance with Kimmel and Connelly (2007), age has no effect on child care and domestic tasks, while it has a positive (quadratic) impact on wives' labour participation (the greatest impact is at around 35 years). The husband/wife age ratio is significant and positive in determining wives' domestic tasks, meaning that wives with a much older husband tend to do more domestic tasks. This is to be expected, since this situation may be a proxy of a very traditional household type.

The individual's and partner's wage rate is positively and significantly associated with more child care for both spouses. This seems to suggest that child care has a positive value per-se and the time spent with children increases with the family's social position (in terms of paid work status). Wages also significantly affect domestic tasks, and in particular the partner's wage rate increases the hours of domestic tasks - a result similar to Bloemen et al (2010). If the estimated model was a collective specification this would have been a sign of the increased bargaining power of the partner when he/she has a larger wage rate. Finally, the wage rate of the wife reduces husband's hours of paid work, while the opposite effect is not observed.

Women with higher education carry out more child care: they may be more conscious that the time parents spend with their children is a strong contribution to a child's development. Husbands' education level, on the other hand, is positively related to time spent in domestic tasks. This may be sign of more modern, non-patriarchal households types. Having no more than a primary education tends to reduce husbands' wage rate. For Italian couples, Bloemen et al (2010) find negative signs for the coefficients of primary school education, both in the husband's and wife's child care equations. On the other hand, for American mothers Kimmel and Connelly (2007) and Connelly and Kimmel (2009) find a negative impact of education on child care time. This discrepancy may be due to the differences in the level of efficiency of the three labour markets. The American labour market is efficient and education allows workers to achieve higher wage rates, while in the Russian and Italian labour markets return on education is low and the opportunity cost of work is small even for educated workers. Moreover, in Russia people with only primary education are still a significant part of the population, as shown in Table 1.

Among household characteristics, household composition is, as expected, one of the main determinants of both child care and domestic tasks. The number of young children, aged 0-3 and 4-6, have a positive impact on fathers' and mothers' hours of child care, with a larger impact for younger children. The number of children aged 0-3 has an impact on domestic tasks, increasing husbands' and reducing wives' hours of domestic tasks. This is a plausible results: when children are small, husbands may substitute for their wives in doing more domestic tasks. Grandparents in the household clearly help with household production, reducing hours of domestic tasks for both males and females, not reducing, however, parents' child care. Finally, non-Russian parents 
dedicate less time to their children and non-Russian wives participate less to the labour market.

The correlation coefficients of the error terms capture the correlation between unobservable factors - both unobserved individual preferences and omitted variables - that influence the equations in the system (5 and 6).

In line with Bloemen et al (2010), Table 4 shows that almost all the estimated correlation coefficients are statistically significant. This means that unobserved preferences of husband and wife can be correlated, which is also a feature of the underlying theoretical model presented in Section "Theoretical foundations". Focusing on child care equations, unobservables of the equation for father's child care are positively correlated with mother's child care, suggesting similar tastes, rather than complementarity, with respect to child care. Positive correlation for child care and domestic tasks between spouses seems to indicate a positive assortative mating, namely, individuals marry each other if they have similar (unobserved) preferences. The same is not true for paid work, since we observe no significant correlations, except for a negative correlation between female child care and paid work, and female domestic tasks and paid work. This is a sign that the explanatory variables were unable to capture all the existing trade-offs between domestic activities and paid work for women. Finally, labour participation is significantly correlated with hours of work for both partners and with the wage equation for wives, confirming the presence of self-selection in the sample.

\section{Conclusions}

The main contribution of this article consists of assessing the influence of alcohol consumption on parental child care. To our knowledge, this is the first study to address the problem of the effects of alcohol consumption on the allocation of time within the household. Building on Becker's hypothesis of altruistic preferences, we assume that parents' utility functions depend on their children's welfare. In turn, the latter is determined by a composite child good that is produced in the household through market goods and child care time. This way, studying the determinants of time spent doing child care, domestic tasks and paid work, permits one to deduce parental preferences towards child welfare.

Empirically, we estimate a system of time supply equations (hours of child care, of domestic tasks and of paid work) integrated with labour market participation and wage equations. Our results show that alcohol consumption of the husband negatively affects his time spent doing child care, but has no effects on his or his spouse's labour supply or wage. In our model, child welfare is determined by child's consumption of a composite good produced by the parents using child care time and market goods. We find that fathers' alcohol consumption significantly reduces child care time without affecting family income, thus reducing child welfare through a reduction of the composite good consumed by his children. We find no effects of mother's alcohol consumption on any time use category, labour participation or wages.

Overall, our findings confirm that alcohol consumption is mainly a male phenomenon, and that it negatively affects other family members. In particular, it seems that fathers' preferences for their children's welfare are reduced by alcohol intake, with a welfare loss for the more vulnerable components of the household. This, jointly with the increasing 
medical and psychological evidence on the damages of alcohol consumption, should be a matter of thorough discussion at the institutional level.

\section{Endnotes}

${ }^{1}$ For a conceptual definition of child care in time use surveys, see Folbre and Yoon (2007).

${ }^{2}$ See Garcia-Mainar et al (2011), and Giannelli et al (2012) for a recent cross-country comparison of intra-household allocation of child care and domestic tasks time.

${ }^{3}$ The authors have explored all the possible causes of the dramatic swings in mortality in the country and found that one of the most important factor is alcohol consumption, especially as it relates to external causes of death such as homicide, suicide and accidents.

${ }^{4}$ Note that the solution of the maximization problem would also provide Marshallian demand functions for market goods, provided that goods expenditure and prices are observed and that a household production technology is assumed. In that case, time use function should also depend on market price of goods. In our empirical setting, however, market good expenditures and prices are not available and $\mathbf{p}^{\prime} \mathbf{x}$ is treated as an endogenously determined total household expenditure and prices are not included in the time use equations.

${ }^{5}$ To avoid notation abuse we do not index observations.

${ }^{6}$ Among the inspected variables, as suggested by previous literature, we tested: average regional alcohol price (in several specifications), average regional alcohol consumption, percentage of alcoholics in the region, past disruptive events (job loss and year of loss), suffering chronic illness (diabetes), and so on. None of these variables were significant in determining alcohol consumption.

${ }^{7}$ Lillard, Lee A. and Constantijn W.A. Panis. 2003. aML Multilevel Multiprocess Statistical Software, Version 2.0. EconWare, Los Angeles, California.

${ }^{8}$ RLMS-HSE site: http://www.cpc.unc.edu/projects/rlms-hse.

${ }^{9}$ For instance, there may be reciprocity of child care between families. Furthermore, it would not be possible to identify whether child care is provided to a subject's own children, or to those of other families within the household.

${ }^{10}$ The first four rounds of Phase II also record time use information, but the measures are not directly comparable and a separate analysis of those years should be carried out, which could be the subject of a future study.

${ }^{11}$ To our knowledge, at the time of writing the only panel study at the household level using RMLS is Lacroix and Radtchenko (2011). Indeed, constructing the household panel is possible only at the cost of dropping conflicting households and the households appearing only once in the sample. Some exploratory investigations led to a drastic reduction of the sample size. This implies that obtaining any meaningful result would have been barely possible.

${ }^{12}$ To clarify, we keep all families in the last round (XVIII). If one of these families is present in other waves we keep only the observation that corresponds to the last wave. Then we add families of round XVII that are not present in XVIII and so on. This way, in the pooled data-set each family appears just once, avoiding over-weighting repeated families. This reduces by a substantial amount the sample size because the majority of the households are present in more than one wave.

${ }^{13}$ Child care time is computed as the sum of two time use questions: 1) Played, occupied, spent your leisure time with children or grandchildren who live with you, and 2) Looked after children or grandchildren who live with you- bathed them, fed them, led them to lessons.

${ }^{14}$ Time devoted to domestic tasks is computed as the sum of 8 time use questions: 1 ) Purchased food goods, 2) Prepared food, 3) Washed dishes, 4) Did laundry, 5) Cleaned rooms 6) Did a small repair of house or dacha, or repaired a car, 7) Did repair work of 
house, dacha and 8) Drove a car with "family" purposes Ü for trips to a store, to the dacha.

${ }^{15}$ Clearly, these figures should not be generalized for the entire Russian population, as they were computed on a restricted sub-sample.

${ }^{16}$ It is well known that identification based uniquely on non-linearity is possible but likely to be problematic.

${ }^{17}$ The aML statistical software does not include facilities for computing marginal/partial effects so we proceeded manually. In doing so we accounted for the censored nature of both child care time and alcohol consumption, and for the logarithmic specification of child care time.

\section{Competing interests}

The IZA Journal of Labor \& Development is committed to the IZA Guiding Principles of Research Integrity. The authors declare that they have observed these principles.

\section{Acknowledgments}

The authors thank Tindara Addabbo, Olga Lazareva, the participants to the XXVII National Conference of Labor Economics (AIEL), the participants to the 26th Annual Conference of the European Society for Population Economics, and an anonymous referee for their useful comments and suggestions. Lucia Mangiavacchi and Luca Piccoli acknowledge financial support from the Spanish Government (Grant ECO2011-28999).

Responsible editor: Hartmut Lehmann

\section{Author details}

${ }^{1}$ Department of Economics, University of Florence and IZA, Via delle Pandette 9, Firenze, Italy. ${ }^{2}$ Department of Applied Economics, University of the Balearic Islands, Ctra de Valldemossa km 7.5, Palma de Mallorca, Spain.

Received: 25 July 2013 Accepted: 11 November 2013

Published: 23 Dec 2013

\section{References}

Amemiya T (1985) Advanced econometrics. Harvard university press

Apps P, Rees R (1996) Labour supply, household production and intra-family welfare distribution. J Pub Econ 60(2): 199-219

Baltagi BH, Geishecker I (2006) Rational alcohol addiction: evidence from the Russian longitudinal monitoring survey. Health Econ 15(9): 893-914

Becker GS (1965) A theory of the allocation of time. Econ J 75(299): 493-517

Becker GS (1981) A Treatise on the Family, enlarged edn. Harvard University Press, Cambridge

Berger G (1993) Alcoholism and the family, franklin watts edn. Franklin Watts, New York

Berger M, Leigh J (1988) The effect of alcohol use on wages. Appl Econ 20(10): 1343-1351

Bloemen H, Pasqua S, Stancanelli E (2010) An empirical analysis of the time allocation of Italian couples: are they responsive? Rev Econ Household 8(3): 345-369

Bourguignon F (1999) The cost of children: may the collective approach to household behavior help? J Popul Econ 12: 503-21

Brainerd E, Cutler D (2005) Autopsy on an empire: Understanding mortality in Russia and the former Soviet Union. J Econ Perspect 19(1): 107-130

Chatterji P, Markowitz S (2001) The impact of maternal alcohol and illicit drug use on children's behavior problems: evidence from the children of the national longitudinal survey of youth. J Health Econ 20(5): 703-731

Chiappori PA (1988) Rational household labor supply. Econometrica 56(1): 63-90

Chiappori PA (1992) Collective labor supply and welfare. J Pol Econ 100(3): 437-67

Connelly R, Kimmel J (2009) Spousal influences on parents' non-market time choices. Rev Econ Household 7(4): 361-394

Dunbar G, Lewbel A, Pendakur K (2013) Children's resources in collective households: identification, estimation, and an application to child poverty in Malawi. Am Econ Rev 103(1): 438-71

Feng W, Zhou W, Butler J, Booth B, French M (2001) The impact of problem drinking on employment. Health Econ 10(6): 509-521

Folbre N, Yoon J (2007) What is child care? Lessons from time-use surveys of major English-speaking countries. Rev Econ Household 5(223-248)

French M, Zarkin G, Mroz T, Bray J (1998) The relationship between drug use and labor supply for young men. Labour Econ 5(4): 385-409

French M, Maclean J, Sindelar J, Fang H (2011) The morning after: alcohol misuse and employment problems. Appl Econ 43(21): $2705-2720$

Garcia-Mainar I, Molina J, Montuenga V (2011) Gender differences in childcare: time allocation in five European countries. Feminist Econ 17(1): 119-150

Giannelli G, Mangiavacchi L, Piccoli L (2012) GDP and the value of family caretaking: how much does Europe care? Appl Econ 44(16)(16): 2111-2131

Grogan L, Koka K (2010) Young children and women's labour force participation in Russia, 1992-2004. Econ Trans 18(4): 715-739

Gronau R (1977) Leisure, Home Production, and Work-the Theory of the Allocation of Time Revisited. J Pol Econ 85(6): 1099-1124 
Grossbard-Shechtman A (1984) A theory of allocation of time in markets for labour and marriage. Econ J 94(376): 863-882 Hallberg D, Klevmarken A (2003) Time for children: A study of parent's time allocation. J Pop Econ 16(2): 205-226 Hamilton V, Hamilton B (1997) Alcohol and earnings: does drinking yield a wage premium? Can J Econ: 135-151 Heckman J (1979) Sample selection bias as a specification error. Econometrica 47(1): 153-162

Kalenkoski C, Ribar D, Stratton L (2007) The effect of family structure on parents' child care time in the United States and the United Kingdom. Rev Econ Household 5(4): 353-384

Kalenkoski C, Ribar D, Stratton L (2009) The influence of wages on parents' allocations of time to child care and market work in the United Kingdom. J Popul Econ 22(2): 399-419

Kalenkoski CM, Ribar DC, Stratton LS (2005) Parental child care in single-parent, cohabiting, and married-couple families: time-diary evidence from the United Kingdom. Am Econ Rev 95(2): 194-198

Kimmel J, Connelly R (2007) Mothers' time choices. J Hum Resour 42(3): 643-681

Kooreman P, Kapteyn A (1987) A disaggregrated analysis of the allocation of time within the household. J Pol Econ 95: 223-249

Lacroix G, Radtchenko N (2011) The changing intra-household resource allocation in Russia. J Popul Econ 24(1): 85-106 Lokshin M (2004) Household childcare choices and women's work behavior in Russia. J Hum Resour 39(4): 1094-1115

Lokshin M, Harris K, Popkin B (2000) Single mothers in Russia: Household strategies for coping with poverty. World Dev 28(12): 2183-2198

MacDonald Z, Shields M (2001) The impact of alcohol consumption on occupational attainment in England. Economica 68(271): 427-453

Mangiavacchi L, Perali F, Piccoli L (2010) Child Welfare in Albania Using a Collective Approach. Tech. rep., Universitat de les Illes Balears, Departament d'Economía Aplicada, WP no 41

Menon M, Perali F, Piccoli L (2012) The Passive Drinking Effect: A Collective Demand Application. University of Verona, Department of Economics, Working Paper no. 05/2012

Mullahy J, Sindelar J (1991) Gender differences in labor market effects of alcoholism. Am Econ Rev 81(2): 161-65

Powell L (2002) Joint labor supply and childcare choice decisions of married mothers. J Hum Resour 37(1): 106-128

Tekin E (2004) Employment, wages, and alcohol consumption in Russia. South Econ J: 397-417

Zarkin G, French M, Mroz T, Bray J (1998) Alcohol use and wages: new results from the national household survey on drug abuse. J Health Econ 17(1): 53-68

Zohoori N, Mroz T, Popkin B, Glinskaya E, Lokshin M, Mancini D, Kozyreva P, Kosolapov M, Swafford M (1998) Monitoring the economic transition in the Russian Federation and its implications for the demographic crisis-the Russian Longitudinal Monitoring Survey. World Dev 26(11): 1977-1993

10.1186/2193-9020-2-13

Cite this article as: Giannelli et al:: Do parents drink their children's welfare? Intra-household allocation of time between market labour, domestic work and child care in Russia. IZA Journal of Labor \& Development 2013, 2:13

\section{Submit your manuscript to a SpringerOpen ${ }^{\circ}$ journal and benefit from:}

$\checkmark$ Convenient online submission

- Rigorous peer review

- Immediate publication on acceptance

- Open access: articles freely available online

- High visibility within the field

- Retaining the copyright to your article

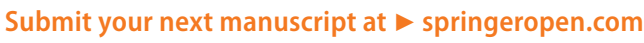

